Exp. Anim. 35(2), 131-138, 1986

\title{
Faded, a Mutation in the KSB Strain of Mouse which Shows Age-related Pigment Change
}

\author{
Yang-Seok OH, Takeshi TOMITA and Kyoji KONDO \\ Laboratory of Animal Genetics, Faculty of Agriculture, Nagoya University, \\ Furo-Cho, Chikusa-ku, Nagoya, 464, Japan
}

(Received 9 April 1985/Accepted 29 October 1985)

\begin{abstract}
Mice with a strange coat color were found in the KSB strain and separated as KSB- $f e$ after fixation for this gene. These mutant mice have faded coat color (black becomes gray), with white underfur, the pigment chaning towards white accompanied by frequent skin lesions. Faded homozygotes show a loss of pigment granules with ageing. Genetic studies were conducted with mice bearing this faded coat color. The mode of inheritance of the faded coat color was established to be autosomal recessive and the name faded ( $f e$ ) was proposed. Faded was not allelic to dilute $(d)$, leadend $(l n)$, beige $(b g)$ or pink-eyed dilution $(p)$ loci.
\end{abstract}

In September, 1979, a single mouse with a strange coat color was found in the second litter of 4 from a pair of KSB strain individuals maintained at the Laboratory of Animal Genetics, Nagoya University. Two more mice with the same coat color were found among the eight offspring of subsequent litters from the same pair. Animals with this strange coat color differed from their litter mates in having a faded coat color, with white underfur, and age-related loss of pigment. The original description of KSB has been given in detail elsewhere $[8,14]$.

The faded mice were crossed with each other and the coat color was fixed and separated from KSB. The faded substrain has been tentatively called $\mathrm{KSB}-f e$.

A number of loci are known to have mutant genes that reduce the intensity of skin and hair pigmentation in the mouse. These loci include dilute $(d)$, leaden $(l n)$, pink-eyed dilution $(p)$, ruby eye $(r u)$, ruby eye-2 (ru$2)$, misty $(m)$, pallid (pa) [13], muted $(m u)$ [7], mocha $(m h)$ [5], pale ear $(e p)$ and light ear (le) [4], ashen (ash) [6], beige (bg) [11], reduced pigmentation $(r p)[1]$, etc.. These genes produce coat color deviants which are phenotypically very similar and difficult to distinguish from each other.

Although many pigment mutations, like those described above are known, only a few genes that cause age-related pigment changes such as greying with age $(G a)[2]$, and silver (si) [13] have been found in mice. Because on the age-related pigment changes, $\mathrm{KSB}-f e$ could be used as an animal model for cellular differentiation.

In this study, an attempt has been made to clarify the biological characteristics and establish the mode of inheritance of coat color in $\mathrm{KSB}-f e$.

\section{Materials and Methods}

Animals: The strains used for crosses with $\mathrm{KSB}-f e$ in this study were $\mathrm{KSB}, \mathrm{C} 57 \mathrm{BL} / 6$, $\mathrm{DBA} / 2, \mathrm{PAN}, \mathrm{C} 57 \mathrm{BL} / 6-b g, \mathrm{CBA} / \mathrm{Ms}$ and $\mathrm{LN}$. KSB was established by Kondo et al. [3] and has aaBBCCDDss coat color genotype. PAN was a hybrid bred in our laboratory between C57BL/ 6 and PINK (which was obtained from a Japanese dealer), having an aaBBCCDDSSpp 
coat color genotype. The others, C57BL/6, $\mathrm{DBA} / 2$, and $\mathrm{CBA} / \mathrm{Ms}$ were introduced from the U.S. A. to Kyoto University, Takeda Chemical Industries, and the National Institute of Genetics, respectively, and subsequently maintained in our laboratory. C57BL/6-bg mice, which carry the mutant allele for beige, were kindly supplied by Dr. Hayakawa of Kanazawa University. LN(aaBBCCDDSSlnln) which was bred for use in a linkage test by Dr. Oda [9], was introduced from the Research Institute of Environmental Medicine, Nagoya University.

All animals were mated at about 40 days of age and the offspring were weaned at approximately 20 days of age. The animals were housed in wooden cages with free access to water. They were fed commercial adult chicken feed (Nihon Nosan Ind. Co. Ltd., Japan), but after parturiton they were fed on commercial diet for reproduction of laboratory mice (Oriental Yeast Co. Ltd., Japan). Room temperature was not controlled, but in winter, heating was applied to keep the room temperature above $10^{\circ} \mathrm{C}$. Body weight was measured once a week and bedding was changed whenever necessary. During this period, general observations were made on the animals. The reproduction ability was observed urtil 180 days of age, and other characteristics such as skin lesions or coat color was observed until 1 year of age.

Hair phenotypes : Among several kinds of hair, awls were examined because they clearly showed abundant pigment granules. Awls were gently plucked from the backs of animals and the hairs were dehydrated in alcohol and cleared in xylene. The morphology of the hair and its pigment were described using the terms defined by Russel [12].

Mating test : Reciprocal outcrosses for genetic analysis were carried out between KSB- $f e$ and $\mathrm{KSB}$ as well as $\mathrm{C} 57 \mathrm{BL} / 6$. The resulting $\mathrm{F} 1$ mice were crossed with each other for F2 segregation, and backcrossed to KSB-fe for backcross segregation.

Allelism test crosses were made between $\mathrm{KSB}-f e$ and $\mathrm{DBA} / 2, \mathrm{LN}, \mathrm{PAN}$, and $\mathrm{C} 57 \mathrm{BL} / 6-$ $b g$.

\section{Results}

An animal with a strange coat color appeared in the 59th generation of KSB strain in September, 1979. The same pair produced two more mice with the same coat color in subsequent matings. These animals with strange coat color were crossed and all progeny from the crosses showed the same faded coat color. They were separated from parental KSB and subsequently maintained by brother-sister matings as $\mathrm{KSB}-f e$.

Body weight and litter size were not decreased when compared with KSB. But affected individuals showed several differences such as poor parturition, a faded coat color (black becoming grey) (Fig. 1), with white underfur (the proximal region of hairs was white), agerelated loss of pigment, and a higher frequency of skin lesions such as edema and bleeding compared with KSB.

At about 15 days of age KSB- $f e$ could be distinguished from KSB by a slight difference in coat color. When raised up to 1 year of age, the colored regions of KSB- $f e$ mice had become almost white. Faded showed no different effects in black and agouti background mice, the offspring of which were observed from test crosses with $\mathrm{C} 57 \mathrm{BL} / 6$ and CBA. With the agouti background, faded appeared almost white at 1 year of age. With the black background the faded effect was also observed but the mice were not as white as in the case of agouti. Microscopic observation of KSB- $f e$ mice revealed that the pigment granules in the body hair were much fewer than those found in the original KSB mice as well as C57/BL/6 (Fig. 2). KSB-fe mice generally lost hair pigment granules with ageing. Pigment granules in the proximal region began to disappear in infants which could be distinguished from KSB. Pigment granules in the distal region occasionally remained to from flocculent clumps in the adult.

Occurrence of skin lesions is shown in Table 2. The KSB strain showed $2.1 \%$, while KSB- $f e$ showed $26.2 \%$ of skin lesions. The age of occurrence of skin lesions seemed to be 


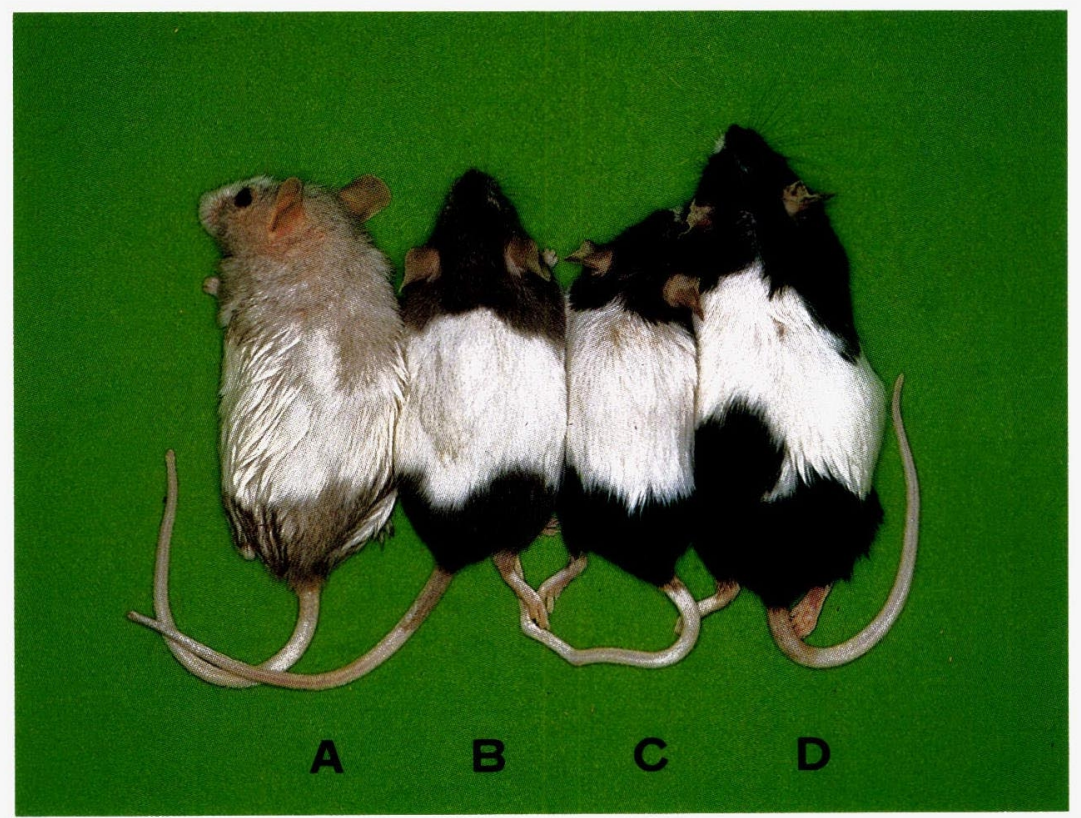

Fig. 1. Dorsal views of (A) 1 year of KSB- $f e$, (B) 80 days of KSB- $f e$ (C) 80 days of KSB and (D) 1 year of KSB mice. (A) and (B) showed a faded coat color, but (A) showed a notable faded effect in comparison with (B). 

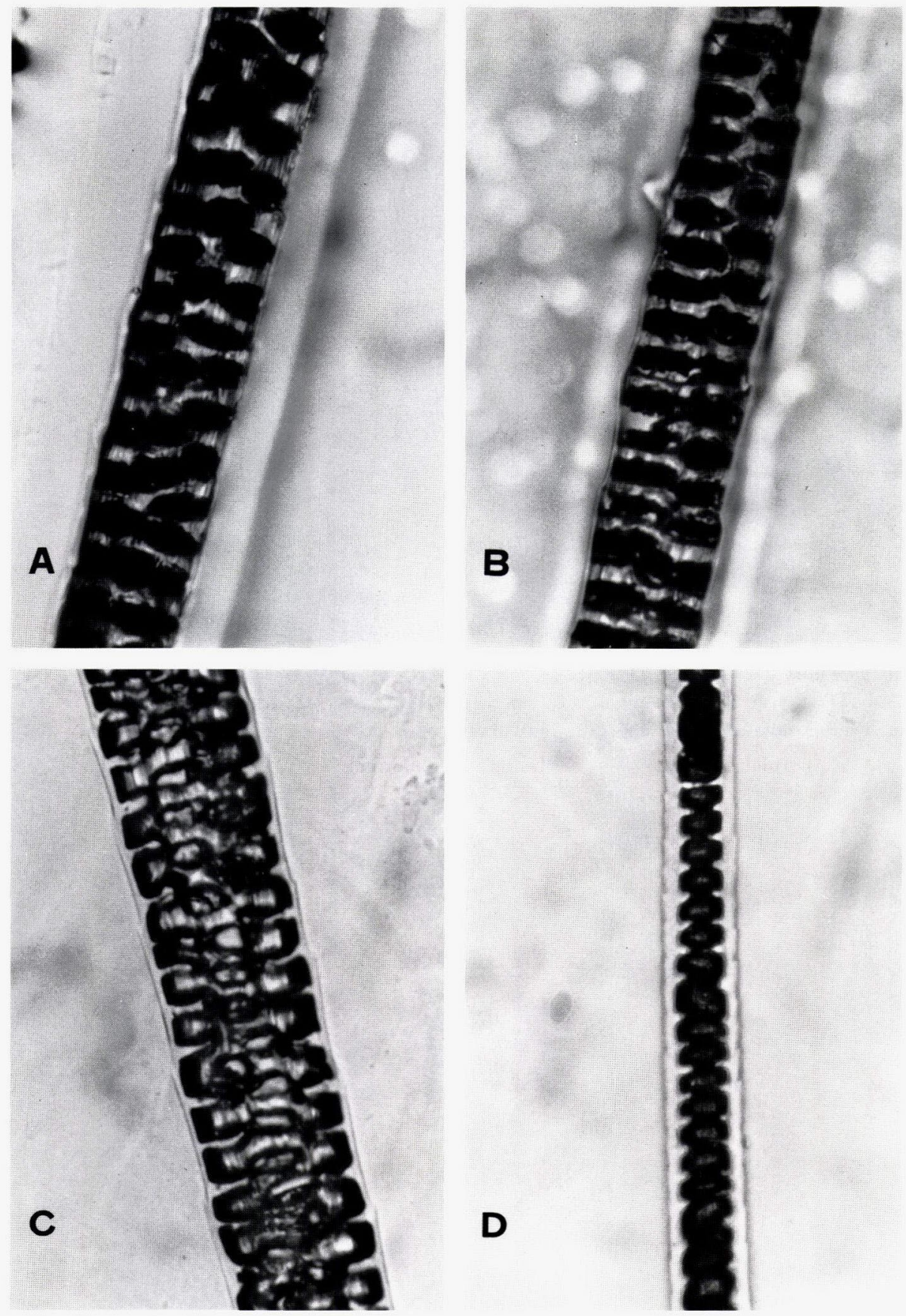

(A) A hair from a C57BL/6 $(+/+)$ mouse. Note the pigment granules in the medulla. (B) A Hair from a $\mathrm{KSB}(+/+)$ mouse showing normal pigment granules. (C) Proximal region of a hair from a KSB- $f e(f e / f e)$ mouse, showing a loss of pigment granules in the medulla. (D) Distal region of a hair from a KSB- $f e(f e / f e)$ mouse, showing flocculent clumps and remaining pigment granules.

Fig. 2. Pigment granules in the hairs of mice. Approx. $\times 600$. 
Table 1. Comparison of biological characteristics between KSB-fe and KSB

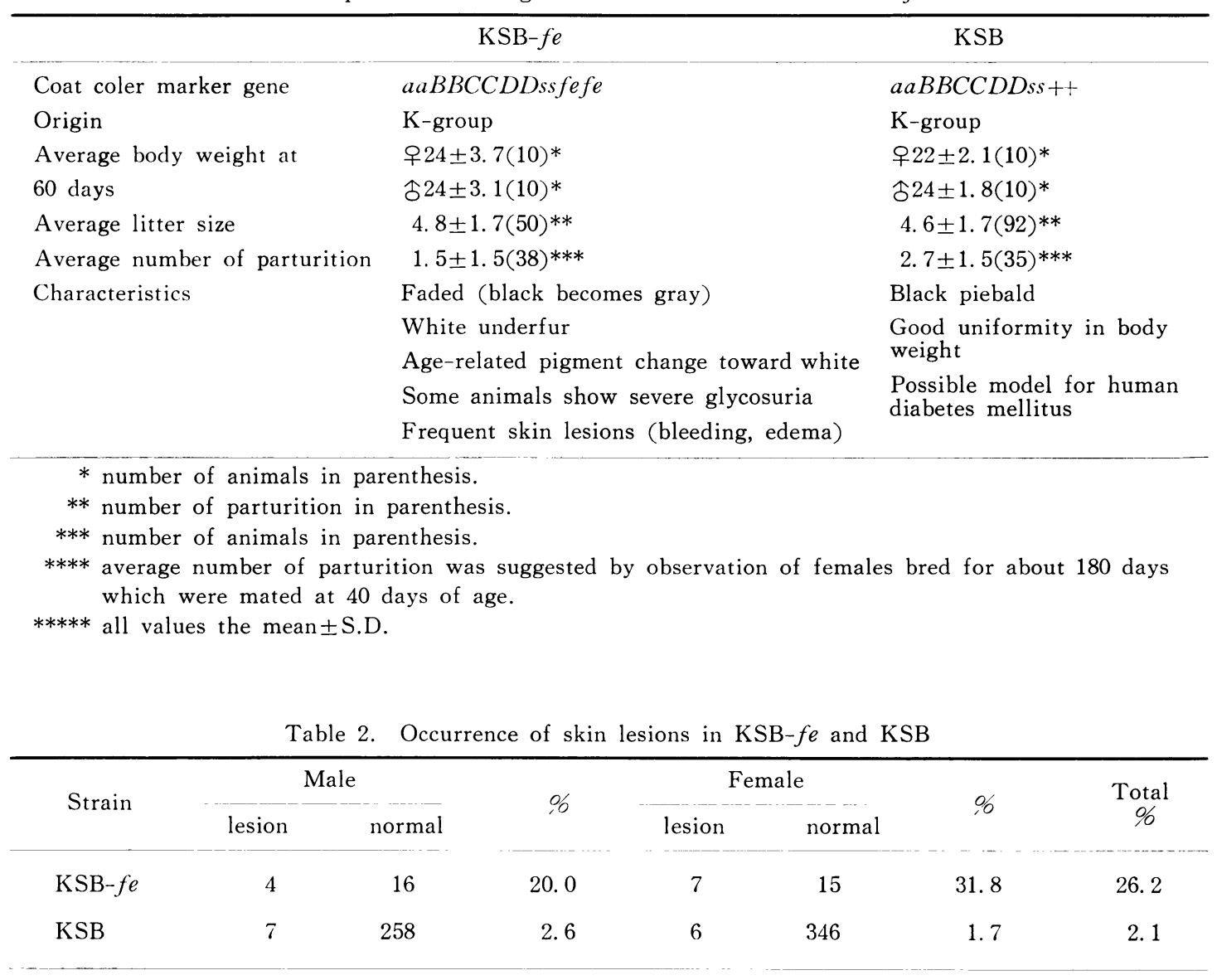

Table 3. Results of test crosses between KSB-fe and KSB

\begin{tabular}{|c|c|c|c|c|c|}
\hline Mating & \multirow{2}{*}{$\begin{array}{c}\text { No. } \\
\text { pairs }\end{array}$} & \multirow{2}{*}{$\begin{array}{c}\text { Total } \\
\text { No. } \\
\text { observed }\end{array}$} & \multicolumn{2}{|c|}{ Phenotypes of offspring } & \\
\hline Dam & & & Black piebald & Faded piebald & \\
\hline $\operatorname{normal}(+/+) \times \operatorname{normal}(+/+)$ & 12 & 209 & 209 & & \\
\hline $\operatorname{faded}(f e / f e) \times \operatorname{faded}(f e / f e)$ & 13 & 156 & & 156 & \\
\hline $\operatorname{normal}(+/+) \times \operatorname{faded}(f e / f e)$ & 2 & 15 & 15 & & \\
\hline $\operatorname{faded}(f e / f e) \times \operatorname{normal}(+/+)$ & 1 & 17 & 17 & & \\
\hline Total & 3 & 32 & 32 & & \\
\hline carrier $(+/ f e) \times$ carrier $(+/ f e)$ & 2 & 41 & 28 & 13 & $0.984^{a}$ \\
\hline carrier $(+/ f e) \times \operatorname{faded}(f e / f e)$ & 1 & 15 & 5 & 10 & \\
\hline $\operatorname{faded}(f e / f e) \times \operatorname{carrier}(+/ f e)$ & 1 & 20 & 12 & 8 & \\
\hline Total & 2 & 35 & 17 & 18 & $0.028^{\mathrm{b})}$ \\
\hline
\end{tabular}

a; expected segregation ratio, $3: 1 ; 0.50>\mathrm{P}>0.25$

$\mathrm{b}$; expected segregation ratio, $1: 1 ; 0.75>\mathrm{P}>0.50$ 
Table 4. Results of test crosses between KSB-fe and C57BL/6

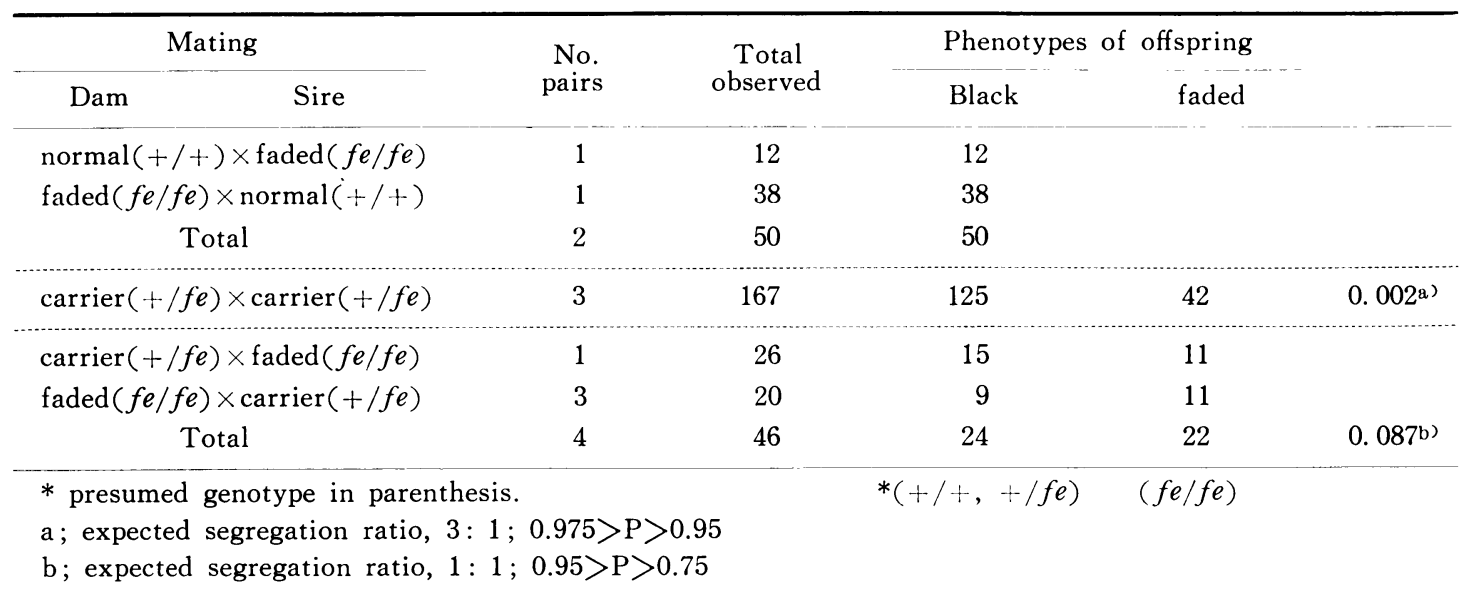

Table 5. Results of allelism test crosses involving faded $(f e)$, dilute $(d)$, pink-eyed dilution $(p)$, beige $(b g)$ and leaden $(l n)$

\begin{tabular}{lccccc}
\hline Mating & Total number of classified & \multicolumn{3}{c}{ Phenotypic classification } \\
\hline$f e / f e \times d / d$ & 38 & + & $d$ & $f e$ & $d, f e$ \\
& & 38 & 0 & 0 & 0 \\
$f e / f e \times p / p$ & 62 & + & $p$ & $f e$ & $p, f e$ \\
& & 62 & 0 & 0 & 0 \\
$f e / f e \times b g / b g$ & 10 & + & $b g$ & $f e$ & $b g, f e$ \\
& & 10 & 0 & 0 & 0 \\
$f e / f e \times \ln / \ln$ & 24 & + & $\ln$ & $f e$ & $\ln , f e$ \\
& & 24 & 0 & 0 & 0 \\
\hline
\end{tabular}

earlier and lesions developed more quickly in $\mathrm{KSB}-f e$ than in KSB. The animals with skin lesions lost body weight and death subsequently followed. The skin lesions started from the rump and then proceeded up the abdomen. Some of these animals had posterior paralysis, with frequent bleeding.

Genetic investigations with faded were then conducted. The faded coat color of all the offspring in the F1 progeny between KSB and $\mathrm{KSB}-f e$ was black piebald while that of all $\mathrm{F} 1$ between $\mathrm{KSB}-\mathrm{fe}$ and $\mathrm{C} 57 \mathrm{BL} / 6$ were black, and there were no differences between reciprocal crosses. Tables 3 and 4 show that the backcrossed animals segregated into approximately equal numbers of mutant and non-mutant phenotypes. There was no significant difference in the ratio of the two phenotypes between males and females in backcrosses. The segregation ratio in the $\mathrm{F} 2$ progeny agreed with a $3: 1$ ratio for non-mutant and mutant phenotypes. These data indicate that faded coat color is controlled by an autosomal recessive gene.

Allelism tests were carried out with four of the genetic variants affecting coat color. In each case, the $\mathrm{F} 1$ progeny consisted of dark-eyed, non-faded and black animals indicating that faded was not allelic to leaden $(l n)$, dilute $(d)$, beige $(b g)$, or pink-eyed dilution $(p)$. These are shown in Table 5. From these results, it may be concluded that the gene controlling faded coat color is a new autosomal recessive gene. 


\section{Discussion}

Some degree of pigment change with age has been shown to be a feature of greying with age $(\mathrm{Ga})[2]$ and silver (si) [13]. Crosses have not been made between faded and greying with age, and silver to rule out the possiblity that it is allelic with them. But, unlike greying with age, faded is an autosomal recessive. Moreover faded does not seem to be influenced by any maternal effect.

Silver could be quite similar to faded with respect to being an autosomal recessive and having age-related coat color changes. Howeves, it differs from faded in that it shows a decreased silvering effect for an agouti and a yellow background as the animal gets older. Faded mice were white in the proximal region of the hair, called white underfur in this paper, and this seemed different from the white underfur gene (wuf) [13], as wuf does not show an age-related pigment change toward white.

Although faded was not allelic with dilute, leaden, beige or pink-eyed dilution, the morphological appearance of the hair was quite different from normal. Dilute and leaden are due to an aggregation of a high proportion of the pigment granules into large clumps. Faded only occasionally showed flocculent clumps in the distal region of the hair. Pink-eyed dilution is associated with a change in shape and arrangement of eumelanin pigment granules which become thread like, and tend to form flocculent clumps. In addition, there is a reduction in the number of granules. Faded showed a similar effect in terms of the number of granules but the change was related to age. In comparison with albino, which possesses a full complement of pigment granules but is unable to produce pigment stems, faded could produce pigment stems but lost pigment granules. Beige mice had very high clumping in the medulla of hairs but faded did not show this effect.

There are a great number of loci which influence the coat color in the mice described above. Allelic tests with other loci, however, are not necessary, because faded mice can be distinguished because of the progressive change of coat color with ageing.

The loss of pigment granules, the observed tendency toward clumping and the age-related pigment changes that the faded mice showed may be a reflection of physiological effects related to peculiarities of pigment metabolism (see Fig. 2). Tyrosinase converts the colorless amino acid, tyrosine, to melanin. Faded may interfere with this pathway, the hydroxylation of tyrosine to dopa or the oxidation of dopa to dopaquinone.

The original KSB was reported by Nishimura [8] to be a possible model for human diabetes mellitus. The faded mouse also shows some possibilities for use as a model for some human congenital metabolic disease. It showed age-related pigment changes, frequent skin lesions and sporadic ketonuria (unpublished data). Skin lesions are usually associated with phenylketonuria in humans [10]. Some physiological tests are now in progress to determine whether the above characteristics are present in faded mice.

\section{References}

[ 1 ] Gibb, S., Hakansson, E. M., Lundin, L.-G. and Shire, J.G.M. (1981). Reduced pigmentation ( $r p$ ), a new coat colour gene with effects on kidney lysosomal glycosidases in the mouse. Genet. Res. 37, 95-103.

[2] Kirby, G. C. (1974). Greying with age: A coatcolor variant in wild Australian populations of mice. J. Hered. 65, 126-128.

[ 3 ] Kondo, K., Himeno, K., Ikoma, H. and Katsuragi, T. (1953). The breeding in mice. (Japanese with English summary). Nat. Inst. Agri. Series G. 7, 9-27.

[4] Lane, P.W., and Green, E.L. (1967). Pale ear and light ear in the house mouse. J. Hered. 58, 1720.

[5] Lane, P. W., and Deol, M. S. (1974). Mocha, a new coat color and behavior mutation on chromosome 10 of the mouse. J. Hered. 65, 362-364.

[6] Lane, P. W., and Womack, J. E. (1979). Ashen, a new color mutation on chromosome 9 of the mouse. J. Hered. 70, 133-135.

[7] Lyon, M.F., and Meredith, R. (1969). Muted, a new mutant affecting coat colour and otoliths of the mouse, and its position in linkage group XIV. Genet. Res. 14, 163-166.

[8] Nishimura, M. (1969). Breeding of mice strains for diabetes mellitus. Exp. Anim. 18, 147-157.

[9] Oda, S. (1983). Genetical and embryological study of a new microphthalmia mutation in the mouse. 
Ph. D. thesis. Nagoya University (Japanese).

[10] Oura, T. (1979). Phenylketonuria. Shonika Mook (Japanese) 9, 11-21.

[11] Pierro, L.J., and Chase, H.B. (1963). Slate-a new coat color mutant in the mouse. J. Hered. 54, 47-50.

[12] Russel, E. S. (1949). A quantitative histological study of the pigment found in the coat color mutants of the house mouse. IV. The nature of the effects of genetic substitution in five major allelic series. Genetics 34, 146-166.

[13] Silvers, W.K. (1979). The coat colors of mice. A model for mammalian gene action and interaction. Springer-Verlag, New York, Heidelberg, Barlin.

[14] Staats, J. (1980). Standardized nomenclature for inbred strains of mice: Seventh listing. Cancer Research 40, 2083-2128.

\title{
KSB 系統に現われた加齢退色する毛色突然変異の遺伝解析
}

\author{
吳 洋錫·富田 武·近藤恭司 \\ 名古屋大学農学部家畜育種学教室
}

\begin{abstract}
1979年より, 近交系マウス KSB 系統において, 加秢 に伴ない毛色が薄くなるマウスが発見された。これらの 形質を持つ雌, 雄を交配した結果, 同じような形質を持 つ子孫を得たので, KSBから独立させ, KSB- $f e$ (faded) と称する亜系を分離した。この形質をむつマウスでは, 色素が加秢に伴なって失われて行くことと, ひんぱんに 皮周病をおこす形質を持つことを認めた。この形質に関
\end{abstract}

して遺伝子分析を行ない, この形質が常染色体性, 単純, 劣性遺伝子によることを明らかにした。また，対立性検 定の結果, 毛色が薄くなる遺伝子 leaden ( ln), dilute (d), beige $(b g)$, pink-eyed dilution $(p)$ とは異なる 遺伝子座に存在することが判明した。そこで, この新し い笑然変異造伝子を faded $(f e)$ と命名した。 